\title{
Macrobenthos abundance and distribution on a spatially patterned intertidal flat
}

\author{
Ellen J. Weerman ${ }^{1,2,3, *}$, Peter M. J. Herman ${ }^{1}{ }^{,}$Johan van de Koppel ${ }^{1}$ \\ ${ }^{1}$ Centre for Estuarine and Marine Ecology, Netherlands Institute of Ecology (NIOO-KNAW), PO Box 40, 4400 AC Yerseke, \\ The Netherlands \\ ${ }^{2}$ Aquatic Ecology and Ecotoxicology (IBED), University of Amsterdam, PO Box 94240, 1090 GE Amsterdam, The Netherlands \\ ${ }^{3}$ Present address: University of Groningen, Community and Conservation Ecology Group, PO BOX 11103, \\ 9700 CC Groningen, The Netherlands
}

\begin{abstract}
Natural ecosystems can show regular spatial vegetation patterns, which develop from small-scale ecological interactions. Some studies suggest that grazers can play a major role in controlling vegetation distribution in ecosystems with regular vegetation patterns, but the distribution of grazers and the effects of grazing on vegetation in spatially patterned ecosystems remains poorly understood. Here, we study how macrofaunal grazers are distributed on a spatially patterned intertidal flat and how they interact with benthic microalgae. The study was carried out on an intertidal flat where each year a regular spatial pattern of diatom-covered hummocks and water-filled hollows develops. In 2 consecutive years, benthic algal biomass was 5 -fold lower in the hollows compared with the hummocks, whereas benthic macrofauna was equally abundant on both hummocks and hollows. In the laboratory we evaluated the interactive effect of landscape morphology (hummocks and hollows) and food abundance. Experiments with 2 abundant grazers, Corophium volutator and Hydrobia ulvae showed that food availability was the main driver for the spatial distribution of benthic herbivores rather than landscape morphology. Laboratory experiments, where we analyzed the grazing effects of $H$. ulvae and $C$. volutator on benthic algal biomass, revealed that both species increased biomass-specific primary production. This could indicate that benthic grazers can stimulate algal growth, which may explain the high grazer abundances in nearly bare hollows. Increased production of benthic algae may be a key factor uncoupling herbivore density from benthic algal biomass on a spatially patterned intertidal flat.
\end{abstract}

KEY WORDS: Corophium volutator - Hydrobia ulvae - Microphytobenthos · Intertidal flats · Landscape morphology

Resale or republication not permitted without written consent of the publisher

\section{INTRODUCTION}

Natural ecosystems can exhibit strikingly regular spatial patterns that develop from local feedback processes between organisms and the physical environment. Regular landscape patterns have been described in various ecosystems, among which tiger bush in arid ecosystems (Klausmeier 1999), striped oligotrophic peat lands in boreal regions (Eppinga et al. 2009) and mussel beds in intertidal systems (van de Koppel et al. 2005) are well-known examples (reviewed by Rietkerk \& van de Koppel 2008). In cases where pattern formation depends on interactions involving primary producers (e.g. benthic algae or vegetation), theoretical predictions suggest that grazers can have a profound effect on spatial patterns (Kéfi et al. 2007). This may result in irreversible shifts from a spatially patterned to a homogeneous state (Rietkerk et al. 2000, HilleRisLambers et al. 2001, Weerman et al. 2011). Such a shift can be 
expected to feed back on the grazers, but despite the assumed role of herbivores in regularly patterned ecosystems, very little is known about the dynamics of grazers in these interactions.

On intertidal flats, regular spatial diatom patterns can develop in early spring (Weerman et al. 2010, de Brouwer et al. 2000, Paterson et al. 2000). These patterns develop because of an interaction between benthic algae and sedimentary processes (Weerman et al. 2010) and are characterized by regularly spaced, diatom-covered hummocks alternating with almost bare, water-filled hollows (de Brouwer et al. 2000, Weerman et al. 2010). These patterns have a scale of $\sim 1 \mathrm{~m}$ and occur at muddy intertidal flats that lack a strong hydrodynamic regime (Weerman et al. 2010). Increased herbivore density, as the season progresses, results in rapid degradation as the ecosystem shifts into a homogenous tidal flat by both direct (removal of benthic algae) and indirect (e.g. bioturbation) effects of grazing (Weerman et al. 2011). It remains unstudied how macrobenthic herbivores are distributed in this patchy landscape of elevated diatom-covered hummocks, alternating with water-filled hollows. Moreover, in June the patterns disappear rapidly and benthic diatom abundances are low, hence macrofaunal abundances remain high (Weerman et al. 2011).

Grazers can affect plant biomass directly by reducing plant standing crop, but they also interact with plants indirectly by releasing nutrients or reducing light limitation (McNaughton 1979). This can have an important effect on plant production (McNaughton 1979). The concept of herbivore compensation suggests that at low grazing intensities, primary production increases and has a flow-on effect, which leads to a net increase in grazing intensity. This phenomenon has been described in both terrestrial (McNaughton 1979) and stream ecosystems (Gregory 1983). The feeding mechanism of herbivores could play a role in the effect they have on primary production. In this study, we test 2 abundant macrofaunal grazers, the amphipod Corophium volutator and the gastropod Hydrobia ulvae, with contrasting feeding modes. Both species are mainly deposit feeders and feed predominantly on benthic diatoms. They have significantly different feeding behaviours and therefore might affect their environment in different ways. H. ulvae mixes the sediment horizontally (Orvain et al. 2006) while browsing the sediment for diatoms (Jensen \& Siegismund 1980, Levinton \& Dewitt 1989). Feeding by C. volutator mixes the sediment vertically, as it feeds from semipermanent burrows in the sediment and gathers sediment particles with its enlarged second antennae (Gerdol \& Hughes 1994a,b, Hagerthey et al. 2002, Riisgard \& Schotge 2007). These 2 feeding strategies might result in effects on pattern formation and primary productivity.

This study focuses on macrofauna distribution on a spatially patterned intertidal and the effects grazers can have on benthic microalgae. We expected that macrofauna species prefer the diatom-covered hummocks over almost bare hollows. We carried out a field survey in 2 successive years and measured macrobenthos and benthic algal abundance on the top of the hummocks and the adjacent hollows. To unravel the combined effect of landscape morphology and benthic algal abundance, we manipulated landscape morphology and benthic algal abundance in a laboratory experiment. Finally, in a second laboratory experiment, we investigated the hypothesis that herbivory stimulated benthic microalgal production, as a possible explanation of our field observation of high macrobenthic biomass in the almost bare hollows. Here, Corophium volutator and Hydrobia ulvae were added to benthic microalgae biofilms and their grazing effect on these biofilms was measured after several days. We hypothesized that these macrofauna species have species-specific effects on benthic biofilms as they apply different feeding mechanisms.

\section{MATERIALS AND METHODS}

\section{Field sampling: spatial distribution of benthic microalgae and macrofauna}

We measured the distribution of macrofauna and benthic algae on the intertidal flat Kapellebank. This is a muddy intertidal flat $\left(51^{\circ} 27^{\prime} \mathrm{N}, 3^{\circ} 58^{\prime} \mathrm{E}\right)$ in the Westerschelde, The Netherlands. On this tidal flat, a spatial pattern of diatom-covered hummocks and alternating water-filled hollows develops each spring (Weerman et al. 2010). In both April 2007 and 2008, several samples were taken at random on both hummocks and adjacent hollows at the intertidal flat. At each sampling year, sampling was done at 2 different dates when spatial patterns were intact. On each sampling occasion, 5 paired samples for chlorophyll a (chl a) and 3 paired samples for macrofauna were taken. Chl a content was determined from the upper $2 \mathrm{~mm}$ of the sediment with a $100 \mathrm{ml}$ cut-off syringe (36 mm inner $\varnothing$ ). During the fieldwork, chl a samples were placed on ice and upon arrival in the laboratory the samples were stored at $-80^{\circ} \mathrm{C}$. Pigment was extracted by adding $10 \mathrm{ml} 90 \%$ acetone to lyophi- 
lized sediment followed by chl a quantification by HPLC of the supernatant (Jeffrey \& Humphrey 1975). Macrofauna samples were taken $(\mathrm{n}=5)$ using a core (inner $\varnothing 11 \mathrm{~cm}, 20 \mathrm{~cm}$ deep) next to the samples for chl a content. The cores were sieved through $0.5 \mathrm{~mm}$ mesh and fixed with a neutralised $8 \%$ formalin solution. Prior to analysis, samples were stained using $0.01 \%$ Rose Bengal. The macrofauna obtained from the cores were identified to genus level.

\section{Material collection and preparation for laboratory experiments}

Sediment was collected at the Kapellebank. After collection, the sediment was mixed and defaunated by freezing it at $-20^{\circ} \mathrm{C}$ for at least $24 \mathrm{~h}$. Prior to the experiment, sediment was thawed and placed in the experimental units (see 'Grazing effects on benthic algae' below). Benthic algae were collected at the Kapellebank by scraping off the top layer of the sediment $(\sim 3 \mathrm{~mm})$. Macrofauna and most of the meiofauna were obtained by sieving $(150 \mu \mathrm{m}$ mesh) the sediment with filtered seawater $(0.45 \mu \mathrm{m})$. Benthic algae were mixed with filtered seawater to create a mixture of benthic algae, small sediment particles and other organic material. This suspension was sprayed on a defaunated sediment layer of $5 \mathrm{~cm}$ thickness. This setup was subsequently cultured for $1 \mathrm{wk}$ to form a benthic microalgae biofilm. Adult Corophium volutator were collected at Kapellebank by sieving sediment (up to $10 \mathrm{~cm}$ depth; $1 \mathrm{~mm}$ mesh) and adult Hydrobia ulvae were collected $20 \mathrm{~km}$ east of the Kapellebank on an intertidal flat near Ritthem $\left(51^{\circ} 27^{\prime} \mathrm{N}, 3^{\circ} 39^{\prime} \mathrm{E}\right)$ by sieving the top layer of the sediment $(1 \mathrm{~cm} ; 1 \mathrm{~mm}$ mesh). Both grazers were allowed to adapt to the experimental conditions for $2 \mathrm{wk}$. Experimental conditions were equal for all experiments. A tidal regime was applied $(6 \mathrm{~h}$ low: $6 \mathrm{~h}$ high) using filtered seawater. Light intensity was $120 \pm 4 \mu \mathrm{W} \mathrm{cm}^{-2}$ (mean $\pm \mathrm{SEM}$ ), with a cycle of $12 \mathrm{~h}$ light: $12 \mathrm{~h}$ dark, and temperature was set at $13^{\circ} \mathrm{C}$ in the laboratory.

\section{Experimental design of the laboratory experiments}

We conducted laboratory experiments to test whether the distribution of the grazers Hydrobia ulvae and Corophium volutator is affected by landscape morphology or food abundance. We created artificial hummocks, hollows and flat sediment, both in the absence and presence of benthic algae. Ten tidal tanks $(30 \times 40 \times 10 \mathrm{~cm})$ were established in a temperature-controlled room and filled with defaunated sediment. In each tank a randomized block design with a total of 30 patches $(\varnothing \sim 5 \mathrm{~cm})$ and 6 treatments was created. These treatments included 3 types of landscape morphology (hummock, hollow or flat) and 2 levels of food presence (absent or present). Hummocks were $\sim 2 \mathrm{~cm}$ higher compared with the flat treatments and hollows were $\sim 2 \mathrm{~cm}$ lower compared with the surrounding sediment. One hundred individuals of either $C$. volutator or $H$. ulvae were randomly added to the experimental tank. Preliminary experiments had shown that the settlement of C. volutator took longer compared with $H$. ulvae. Therefore, presence on the patches was counted after $1 \mathrm{~h}$ for $H$. ulvae and after $24 \mathrm{~h}$ for $C$. volutator. In total, 30 replicates of each treatment were applied. Animals could move freely between the patches. The video film in the supplement (www.int-res.com/ articles/suppl/m440p095_supp/) shows the experimental setup and the movement of $H$. ulvae towards the food patches.

\section{Grazing effects on benthic algae}

Laboratory experiments were carried out to measure the effects of macrofaunal grazing on benthic algal biomass and production. Experimental units consisted of PVC cores ( $\varnothing$ 12.5, $10 \mathrm{~cm}$ height) filled with defaunated sediment. Benthic algae were scraped off the sediment in the benthic algae culture tanks and mixed with filtered seawater to create a mixture of benthic algae, small sediment particles and other organic material. During low tide, this mixture was sprayed on defaunated sediment in the experimental cores as a thin layer. Biofilms were allowed to grow for $7 \mathrm{~d}$, after which grazers were added at different densities $(0,0.06,0.19$ and 0.38 ind. $\mathrm{cm}^{-2}$ ). After $18 \mathrm{~d}$, when the control cores had reached a steady state, we measured photosynthetic parameters in ungrazed und grazed biofilms using the Imaging Pulse Amplitude Modulated Fluorometer (Imaging PAM, Walz). Benthic algal biomass was measured as maximum fluorescence $\left(F_{\mathrm{m}}\right)$ after 15 min of dark adaptation of the biofilms (Kromkamp et al. 1998, Barranguet \& Kromkamp 2000). There was a good correlation between the $F_{\mathrm{m}}$ values and the chl a concentration (mg C m${ }^{-2}$; Appendix 1); therefore, we converted the $F_{\mathrm{m}}$ values into chl a concentration. Fluorescence measurements were taken during the low-tide cycle. Diatoms in the laboratory did not 
show their natural migratory rhythm; therefore, the time of these measurements during the cycle did not influence the fluorescence signal. Following the $F_{\mathrm{m}}$ measurements, electron transport rate (ETR) measurements were carried out by exposing the biofilms to 10 different photon flux levels, ranging from 0 to $702 \mu \mathrm{mol} \mathrm{m} \mathrm{m}^{-2} \mathrm{~s}^{-1}$. These ETR curves were fitted according to Webb et al. (1974), using the least squares method. In this method, the maximum rate of ETR, the initial slope and the light saturation parameter were calculated to estimate the photosynthetic productivity (mg C m${ }^{-2} \mathrm{~d}^{-1}$ ) of these biofilms according to Barranguet \& Kromkamp (2000). Biomassspecific primary production was calculated by dividing the production $\left(\mathrm{mg} \mathrm{C} \mathrm{m} \mathrm{C}^{-2} \mathrm{~d}^{-1}\right.$ by the chl $a$ concentration $\left(\mathrm{mg} \mathrm{C} \mathrm{m}^{-2}\right)$.

\section{Statistical analysis}

Field collection

The field data were analyzed using a paired $t$-test (2-tailed) to indicate significant differences in benthic algal biomass, Corophium volutator abundance, Hydrobia ulvae abundance or total macrofauna abundance on hummocks compared with adjacent hollows.

\section{Laboratory experiments}

The influence of benthic algal biomass and landscape morphology on Corophium volutator or Hydrobia ulvae abundance was analyzed using a 2-way ANOVA. Here, we tested for interactive effects of the fixed factors of food abundance (present or absent) and landscape morphology (hummock, hollow, flat). To overcome the problem of pseudoreplication, we used tank as a random categorical predictor. The data were checked for normality and homogeneity of variance; appropriate transformation was applied if these criteria were not met (Zar 1999).

\section{Grazing effects}

In the laboratory experiment, we analyzed the effects of grazing on benthic algal biomass, carbon production and biomass-specific production using linear regression. For all statistical analyses, we used $\mathrm{R}$ (www.R-project. org) significance levels were always set at $\mathrm{p}<0.05$.

\section{RESULTS}

\section{Field observations}

Benthic algal biomass was 4 times higher on the hummocks compared to the hollows (Fig. 1A, Table 1). We observed no effects of the benthic algal food abundance on macrofauna distribution, as total macrofaunal, Corophium volutator and Hydrobia ulvae densities were not significantly different between benthic algal-covered hummocks or almost bare hollows in either year (Fig. 1B-D, Table 1).

\section{Laboratory experiments}

We tested whether Hydrobia ulvae or Corophium volutator preferred specific landscape positions (hummock, hollow or flat) or whether they were generally attracted to food-enriched patches $(p<0.01)$. These experiments demonstrated the aggregation of both species in enriched food patches where they showed at least doubled abundances (Fig. 2, Table 2). Landscape morphology did not affect the distribution of $C$. volutator or H. ulvae (Fig. 2B).
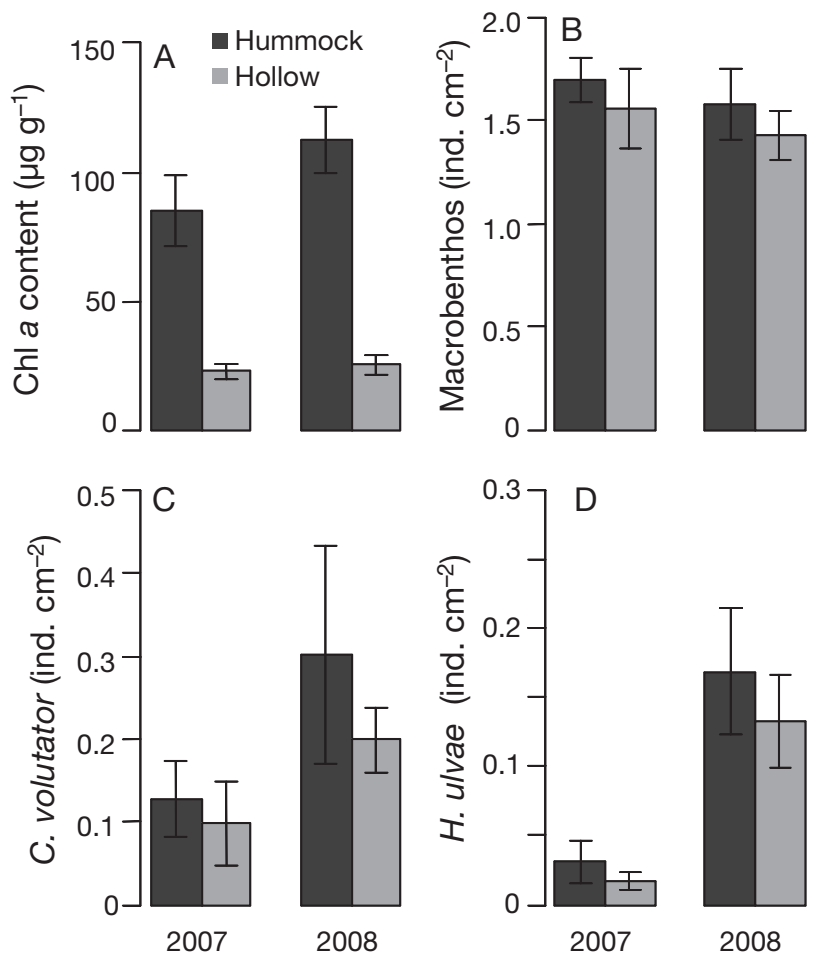

Fig. 1. Field measurements of densities of (A) benthic microalgae biomass, (B) total macrofauna, (C) Corophium volutator and (D) Hydrobia ulvae expressed as individuals per $\mathrm{cm}^{2}$. Black and grey bars indicate abundances on hummocks and in hollows, respectively. Means $\pm \mathrm{SE}$ 
Table 1. Paired $t$-test for the field data on benthic algal biomass, and abundances of Corophium volutator, Hydrobia ulvae, and total macrofauna in April 2007 and 2008 tested for the influence of landscape morphology (hummocks and hollows)

\begin{tabular}{|lcccc|}
\hline \multirow{2}{*}{ Parameter } & \multicolumn{4}{c}{ Landscape morphology } \\
& Year & $t$ & $\mathrm{df}$ & $\mathrm{p}$ \\
\hline Benthic algal biomass & 2007 & 4.37 & 9 & $<0.01$ \\
& 2008 & 6.01 & 9 & $<0.001$ \\
Total macrofauna abundance & 2007 & 0.39 & 6 & 0.70 \\
& 2008 & 0.63 & 5 & 0.55 \\
C. volutator abundance & 2007 & 0.76 & 6 & 0.48 \\
H. ulvae abundance & 2008 & 0.78 & 5 & 0.46 \\
& 2007 & 0.79 & 5 & 0.46 \\
& 2008 & 0.63 & 5 & 0.55 \\
\hline
\end{tabular}

However, in the presence or absence of food, these grazers showed different preferences for landscape morphology, and the interaction term was significant for both C. volutator and H. ulvae (Table 2).

\section{Grazing effects}

Our laboratory grazing experiments revealed an influence of grazers on benthic algal biomass and production. As expected, increasing grazer abundance reduced benthic algal biomass (Fig. 3A, Table 3). At the highest densities, both grazers reduced algal standing stock by $50 \%$. Although similar grazer concentrations showed similar effects on benthic algae removal, primary production was affected differently by species. Carbon production did not

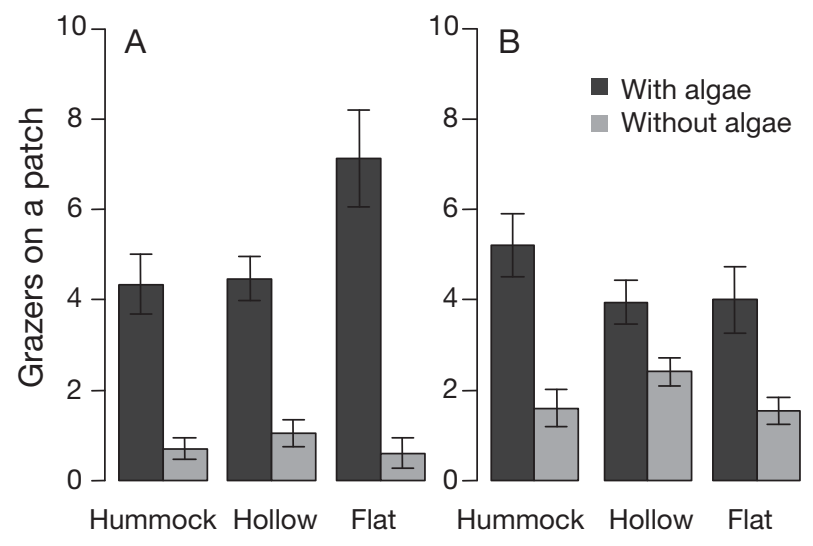

Fig. 2. Abundances of (A) Hydrobia ulvae and (B) Corophium volutator on food-enriched (black bars) and nonfood-enriched patches (grey bars) with the different landscape morphology treatments (hummock, hollow and flat). Means \pm SE
Table 2. Two-way ANOVA for influence of landscape morphology, food abundance (benthic algae) and landscape morphology $\times$ food abundance on Corophium volutator and Hydrobia ulvae abundances. ns: not significant ( $p>0.05$ )

\begin{tabular}{|lcccccc|}
\hline $\begin{array}{l}\text { Grazer } \\
\text { Factor }\end{array}$ & SS & df & MS & $F$ & $\mathrm{p}$ \\
\hline C. volutator & & & & & \\
$\quad$ Food abundance & 33.36 & 1 & 33.35 & 71.79 & $<0.001$ \\
Landscape morphology & 1.226 & 2 & 0.613 & 1.320 & $\mathrm{~ns}$ \\
Landscape $\times$ Food & 6.894 & 2 & 3.447 & 7.419 & $<0.001$ \\
H. ulvae & & & & & \\
Food abundance & 66.69 & 1 & 66.68 & 139.98 & $<0.001$ \\
Landscape morphology & 0.467 & 2 & 0.233 & 0.491 & $\mathrm{~ns}$ \\
Landscape $\times$ Food & 2.883 & 2 & 1.441 & 3.026 & $<0.001$ \\
\hline
\end{tabular}

change with increasing Corophium volutator abundance, whereas for Hydrobia ulvae a slight but significant decrease was found in primary production with increasing grazer densities (Fig. 3B, Table 3). Biomass-specific production increased similarly with grazing of $C$. volutator and $H$. ulvae (Fig. 3C, Table 3).

\section{DISCUSSION}

In this study, we have investigated the effects of macrobenthic herbivores on primary productivity on an intertidal flat. The enhancement of biomassspecific production and resource heterogeneity could explain the spatial distribution of macrobenthic herbivores. Although clear differences in benthic algal biomass were observed, total macrobenthos abundance was similar on diatom-covered hummocks compared with the adjacent relatively bare hollow. Even though the spatial scale of this study is limited to 1 intertidal flat, similar patterns of macrobenthic herbivores surviving at apparent low benthic algal biomass have been observed in similar systems (Montserrat et al. 2008, de Brouwer et al. 2000). A possible explanation for this phenomenon could be the increased biomass-specific production of benthic algae, induced by both Hydrobia ulvae and Corophium volutator grazing. High primary production rates prevent macrobenthic herbivores from entirely depleting the algae. This compensated production seems to be essential in the apparent insensitivity of benthic herbivores to spatial and temporal variation in the availability of their resources.

Laboratory experiments revealed a clear preference of both Corophium volutator and Hydrobia ulvae to concentrate in patches of high algal biomass, 

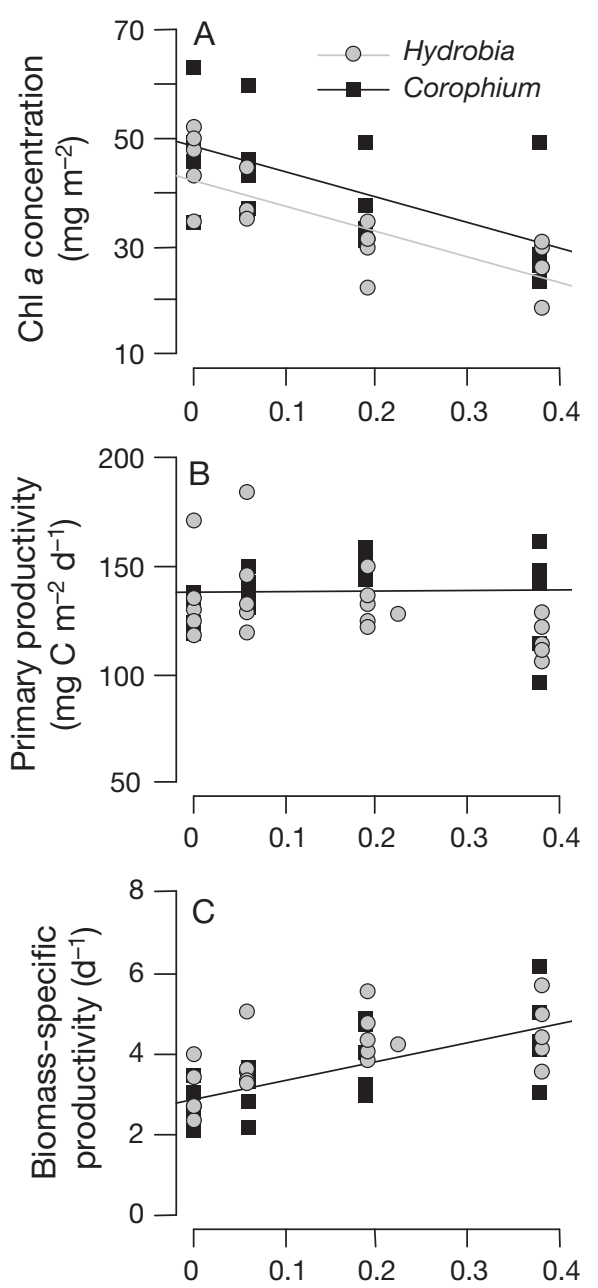

Grazer abundance (ind. $\mathrm{cm}^{-2}$ )

Fig. 3. Laboratory experiment on the grazing effects of Hydrobia ulvae (grey lines; circles) and Corophium volutator (black lines; squares) on (A) benthic algal biomass ( $\mu \mathrm{g}$

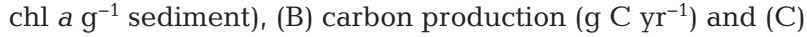
biomass-specific production (area-specific production/algal biomass)

indicating that food availability was the prime determinant of the spatial distribution of these grazers. It is known that both species accumulate in patches with high food abundance (Morrisey 1988a, Lawrie et al. 2000). Mud snails move slower once they have reached high-density food patches (Forbes \& Lopez 1986); along with the ability to follow mucus trail of others (Bretz \& Dimock 1993), this results in a rapid assembly of large groups on abundant food resources. Previous studies also concluded that $C$. volutator aggregates towards patches with higher food abundance (Lawrie et al. 2000, Hamilton et al. 2006). Nevertheless, in the field we could not observe preference for macrofauna between hummocks or hollows
Table 3. Test statistics and p-values for the linear regression analysis of benthic algal biomass, carbon production and biomass-specific production on grazer (Corophium volutator and Hydrobia ulvae) abundance. ns: not significant ( $\mathrm{p}>0.05$ )

\begin{tabular}{|lcccc|}
\hline & $a$ & $b$ & $\mathrm{r}^{2}$ & $\mathrm{p}$ \\
\hline C. volutator & & & & \\
Benthic algal biomass & 152.70 & -14.41 & 0.34 & $<0.01$ \\
Carbon production & 137.65 & 0.4909 & 0.05 & $\mathrm{~ns}$ \\
Biomass-specific production & 0.9119 & 0.144 & 0.41 & $<0.01$ \\
$\boldsymbol{H}$. ulvae & & & & \\
Benthic algal biomass & 134.51 & -15.14 & $0.61<0.001$ \\
$\begin{array}{l}\text { Carbon production } \\
\text { Biomass-specific production }\end{array}$ & 141.26 & -5.88 & 0.17 & $<0.05$ \\
& 1.070 & 0.120 & $0.32<0.01$ \\
\hline
\end{tabular}

even though food concentrations were 5 times higher on top of the hummocks. Field data from a similar intertidal flat showed that benthic macrofauna reached highest densities at intermediate food densities (van der Wal et al. 2008). This suggests that, above a certain minimum benthic algal biomass, macrofauna abundance is relatively independent of algal biomass.

Next to food abundance, we also tested the influence of landscape morphology on the distribution of grazers. We did not find a clear preference of either grazer for hummock, hollows or flat landscapes. However, there was an interaction effect with food availability that indicates that, depending on food availability, both organisms prefer a different landscape type. Previous studies have shown that macrofauna preferably occupy hollows (Barros et al. 2004, Ramey et al. 2009). However, these studies were conducted in the field, which makes it very difficult to distinguish the direct effects of elevation from other factors such as variations in hydrodynamic forcing, silt content and food availability between crests and troughs (Lanuru et al. 2007). Our controlled experiments showed that the prime determinant of species distribution was resource availability and that there were no effects of landscape morphology. We should acknowledge that the field sampling was conducted during low water and during the laboratory experiments high water was simulated. The difference in mobility of the species can be important, as it is not known how they behave during inundation in the field. Even though neither species responds to landscape morphology, they can change landscape morphology (Mouritsen et al. 1998, Weerman et al. 2011). Both species have been shown to increase erodibility of the sediment (Daborn et al. 1993, Andersen et al. 2002, Orvain et al. 2004), thereby disturbing diatom-sediment feedbacks that are respon- 
sible for the hummock-hollow landscape structure (Weerman et al. 2011).

The feeding mode of grazers is an important aspect of the effects that herbivores have on plant primary production (Carpenter 1986, McClanahan 1994). The browser Hydrobia ulvae and the central place forager Corophium volutator have different feeding mechanisms and although the highest grazer abundance we applied in our laboratory study is still quite low compared with peaks in natural abundances, both species reduced diatom biomass in our laboratory experiment (Fig. 3). H. ulvae and C. volutator are known to have a strong effect on benthic algal biomass even at low grazer concentrations (LópezFigueroa 1988, Morrisey 1988b, Gerdol \& Hughes 1994a). Both species also enhanced the biomassspecific production, which indicates that the growth of benthic algae was stimulated by grazing. Initially, we expected that $C$. volutator grazed biofilms would enhance production more compared with $H$. ulvae grazed biofilms. C. volutator mixes and ventilates the sediment much deeper than H. ulvae (Meadows et al. 1990, Orvain et al. 2004). This ventilation may enhance the flux of nutrients to the sediment surface. Because we did not find a difference on biomass-specific productivity between the 2 feeding mechanisms, it is likely that our biofilms were not nutrient limited. Therefore, it is likely that other mechanisms caused the increased biomass-specific productivity, such as changes in taxonomic composition of the benthic algae (Kaehler \& Froneman 2002) or shading (Hill et al. 1995). H. ulvae is a grazer on sub-dominant species, whereas $C$. volutator consumes mostly dominant taxa, which increases species richness (Hagerthey et al. 2002). Both strategies result in a different benthic algae consortium, which can affect biomassspecific productivity.

The results presented in this study show some interesting similarities with the concept of grazing lawns in terrestrial studies. In grazing lawns, herbivory leads to increased plant production and therefore favours grazing-tolerant species. As a consequence, the independence of herbivores from food biomass is enhanced by the increase of biomassspecific production rate as an indirect effect of grazing. This interaction results in a mosaic of heavily grazed patches surrounded by inaccessible bushes (McNaughton 1984). In our intertidal system, grazing was found to stimulate primary production in a similar way. The dense diatom mats on the hummocks in the patterned state could be equivalents to the terrestrial inaccessible bush vegetation. The hollows could be equivalents to the heavily grazed parts where biomass-specific production is increased. However, the analogy with terrestrial systems breaks down in the long run. The bioturbation of macrobenthic organisms disrupts the biophysical feedbacks between diatom growth and sedimentation of fine-grained materials, leading to a dramatic collapse of both benthic algal biomass and the resulting landscape morphology on intertidal mudflats (Weerman et al. 2011). This suggests that by their insensitivity to food abundance, at least in the short term, herbivores can have a profound impact on the spatial structure of ecosystems, similar to what is found in terrestrial ecosystems (Iacobelli \& Jefferies 1991, Jefferies et al. 1994).

Our results revealed that macrofaunal distribution in a patchy landscape is mainly driven by food availability rather than the topography of the sediment. Initially, we expected that macrofauna species preferred the diatom-covered hummocks over almost bare hollows in the field. Surprisingly, we did not find a significant difference in macrofauna biomass on the diatom-covered hummocks compared with almost bare hollows. We then investigated, in a laboratory experiment, the hypothesis that herbivory stimulated microalgal production, providing a possible explanation of the observation of high macrobenthic biomass at locations with low benthic microalgae biomass. These results, combined with our previous work in this ecosystem (Weerman et al. 2010, 2011), revealed that the interactive effects of resource heterogeneity and grazing-induced enhancement of benthic algae production provided a possible explanation for the spatial distribution of macrobenthic grazers on a patterned intertidal flat.

Acknowledgements. The authors thank Dingeman de Visser and Jos van Soelen for their help in the laboratory experiments. Jacco Kromkamp is thanked for his help in analyzing the Imaging-PAM data. This is NIOO publication number 5072 .

\section{LITERATURE CITED}

Andersen TJ, Jensen TK, Lund-Hansen L, Mouritsen KN, Pejrup M (2002) Enhanced erodibility of fine-grained marine sediments by Hydrobia ulvae. J Sea Res 48:51-58

> Barranguet C, Kromkamp J (2000) Estimating primary production rates from photosynthetic electron transport in estuarine microphytobenthos. Mar Ecol Prog Ser 204: $39-52$

Barros F, Underwood AJ, Archambault P (2004) The influence of troughs and crests of ripple marks on the structure of subtidal benthic assemblages around rocky reefs. Estuar Coast Shelf Sci 60:781-790

Bretz DD, Dimock RV (1993) Behaviorally important characteristics of the mucous trail of the marine gastropod 
Ilyanassa obsoleta (Say). J Exp Mar Biol Ecol 71:181-191

Carpenter RC (1986) Partitioning herbivory and its effects on coral reef algal communities. Ecol Monogr 56: 345-363

> Daborn GR, Amos CL, Brylinsky M, Christian H and others (1993) An ecological cascade effect: migratory birds affect stability of intertidal sediments. Limnol Oceanogr 38:225-231

> de Brouwer JFC, Bjelic S, de Deckere E, Stal LJ (2000) Interplay between biology and sedimentology in a mudflat (Biezelingse Ham, Westerschelde, The Netherlands). Cont Shelf Res 20:1159-1177

> Eppinga MB, de Ruiter PC, Wassen MJ, Rietkerk M (2009) Nutrients and hydrology indicate the driving mechanisms of peatland surface patterning. Am Nat 173: 803-818

> Forbes VE, Lopez GR (1986) Changes in feeding and crawling rates of Hydrobia truncata (Prosobranchia: Hydrobiidae) in response to sedimentary chlorophyll-a and recently egested sediment. Mar Ecol Prog Ser 33:287-294

Gerdol V, Hughes RG (1994a) Effect of Corophium volutator on the abundance of benthic diatoms, bacteria and sediment stability in two estuaries in southeastern England. Mar Ecol Prog Ser 114:109-115

Gerdol V, Hughes RG (1994b) Feeding behavior and diet of Corophium volutator in an estuary in southeastern England. Mar Ecol Prog Ser 114:103-108

Gregory SV (1983) Plant-herbivore interactions in stream systems. In: Barnes JR, Minshall GW (eds) Stream ecology. Plenum Press, New York, NY, p 157-189

> Hagerthey SE, Defew EC, Paterson DM (2002) Influence of Corophium volutator and Hydrobia ulvae on intertidal benthic diatom assemblages under different nutrient and temperature regimes. Mar Ecol Prog Ser 245:47-59

Hamilton DJ, Diamond AW, Wells PG (2006) Shorebirds, snails, and the amphipod (Corophium volutator) in the upper Bay of Fundy: top-down vs. bottom-up factors, and the influence of compensatory interactions on mudflat ecology. Hydrobiologia 567:285-306

Hill WR., Ryon MG, and Schilling EM. (1995). Light limitation in a stream ecosystem responses by primary producers and consumers. Ecology 76:1297-1309

> HilleRisLambers R, Rietkerk M, van den Bosch F, Prins HHT, de Kroon H (2001) Vegetation pattern formation in semiarid grazing systems. Ecology 82:50-61

> Honeywill C, Paterson DN, Hagerthey SE (2002) Determination of microphytobenthic biomass using pulse-amplitude modulated minimum fluorescence. Eur J Phycol 37: 485-492

> Iacobelli A, Jefferies RL (1991) Inverse salinity gradients in coastal marshes and the death of stands of Salix: the effects of grubbing by geese. J Ecol 79:61-73

$>$ Jefferies RL, Klein DR, Shaver GR (1994) Vertebrate herbivores and northern plant communities: reciprocal influences and responses. Oikos 71:193-206

Jeffrey SW, Humphrey GF (1975) New spectrophotometric equations for determining chlorophylls a, b, c1 and c2 in higher-plants, algae and natural phytoplankton. Biochem Physiol Pflanz 167:191-194

Jensen KT, Siegismund HR (1980) The importance of diatoms and bacteria in the diet of Hydrobia species. Ophelia 17:193-199

Kaehler S, Froneman PW (2002) Herbivore-mediated increase in the photosynthetic capacity of marine biofilms: indirect effects of changing microalgal assemblage com- position. Mar Ecol Prog Ser 234:15-22

Kéfi S, Rietkerk M, Alados CL, Pueyo Y, Papanastasis VP, ElAich A, de Ruiter PC (2007) Spatial vegetation patterns and imminent desertification in Mediterranean arid ecosystems. Nature 449:213-215

Klausmeier CA (1999) Regular and irregular patterns in semiarid vegetation. Science 284:1826-1828

> Kromkamp J, Barranguet C, Peene J (1998) Determination of microphytobenthos PSII quantum efficiency and photosynthetic activity by means of variable chlorophyll fluorescence. Mar Ecol Prog Ser 162:45-55

> Kromkamp JC, Morris EP, Forster RM, Honeywill C, Hagerthey S, Paterson DM (2006) Relationship of intertidal surface sediment chlorophyll concentration to hyperspectral reflectance and chlorophyll fluorescence. Estuaries Coasts 29:183-196

Lanuru M, Riethmüller R, van Bernem C, Heymann K (2007) The effect of bedforms (crest and trough systems) on sediment erodibility on a back-barrier tidal flat of the East Frisian Wadden Sea, Germany. Estuar Coast Shelf Sci 72: $603-614$

Lawrie SM, Raffaelli DG, Emes CH (2000) Small-scale patterns in the distribution of the amphipod Corophium volutator on the Ythan estuary, Aberdeenshire, Scotland. Sarsia 85:321-327

Levinton JS, Dewitt TH (1989) Relation of particle-size spectrum and food abundance to particle selectivity in the mud snail Hydrobia totteni (Prosobranchia, Hydobiidae). Mar Biol 100:449-454

> López-Figueroa FN, Niell FX (1988) Feeding behaviour of Hydrobia ulvae (Pennant) in microcosms. J Exp Mar Biol Ecol 114:153-167

McClanahan TR (1994) Coral-eating snail Drupella cornus population increases in Kenyan coral reef lagoons. Mar Ecol Prog Ser 115:131-137

McNaughton SJ (1979) Grazing as an optimization process: grass-ungulate relationships in the Serengeti. Am Nat 113:691-703

McNaughton SJ (1984) Grazing lawns: animals in herds, plant form, and coevolution. Am Nat 124:863-886

Meadows PS, Tait J, Hussain SA (1990) Effects of estuarine infauna on sediment stability and particle sedimentation. Hydrobiologia 190:263-266

Montserrat F, Van Colen C, Degraer S, Ysebaert T, Herman PMJ (2008) Benthic community-mediated sediment dynamics. Mar Ecol Prog Ser 372:43-59

Morrisey DJ (1988a) Differences in effects of grazing by deposit-feeders Hydrobia ulvae (Pennant) (Gastropoda, Prosobranchia) and Corophium arenarium Crawford (Amphipoda) on sediment microalgal populations. I. Qualitative differences. J Exp Mar Biol Ecol 118:33-42

> Morrisey DJ (1988b) Differences in effects of grazing by deposit-feeders Hydrobia ulvae (Pennant) (Gastropoda, Prosobranchia) and Corophium arenarium Crawford (Amphipoda) on sediment microalgal populations. II. Quantitative effects. J Exp Mar Biol Ecol 118:43-53

Mouritsen KN, Mouritsen LT, Jensen KT (1998) Change of topography and sediment characteristics on an intertidal mud-flat following mass-mortality of the amphipod Corophium volutator. J Mar Biol Assoc UK 78: 1167-1180

> Orvain F, Sauriau PG, Sygut A, Joassard L, Le Hir P (2004) Interacting effects of Hydrobia ulvae bioturbation and microphytobenthos on the erodibility of mudflat sediments. Mar Ecol Prog Ser 278:205-223 
Orvain F, Sauriau PG, Bacher U, Prineau M (2006) The influence of sediment cohesiveness on bioturbation effects due to Hydrobia ulvae on the initial erosion of intertidal sediments: a study combining flume and model approaches. J Sea Res 55:54-73

Paterson DM, Tolhurst TJ, Kelly JA, Honeywill C and others (2000) Variations in sediment properties, Skeffling mudflat, Humber Estuary, UK. Cont Shelf Res 20:1373-1396

Ramey PA, Grassle JP, Grassle JF, Petrecca RF (2009) Smallscale, patchy distributions of infauna in hydrodynamically mobile continental shelf sands: Do ripple crests and troughs support different communities? Cont Shelf Res 29:2222-2233

Rietkerk M, van de Koppel J (2008) Regular pattern formation in real ecosystems. Trends Ecol Evol 23:169-175

Rietkerk M, Ketner P, Burger J, Hoorens B, Olff H (2000) Multiscale soil and vegetation patchiness along a gradient of herbivore impact in a semi-arid grazing system in West Africa. Plant Ecol 148:207-224

Riisgard HU, Schotge P (2007) Surface deposit feeding versus filter feeding in the amphipod Corophium volutator.
Mar Biol Res 3:421-427

van de Koppel J, Rietkerk M, Dankers N, Herman PMJ (2005) Scale-dependent feedback and regular spatial patterns in young mussel beds. Am Nat 165:E66-E77

> van der Wal D, Herman PMJ, Forster RM, Ysebaert T and others (2008) Distribution and dynamics of intertidal macrobenthos predicted from remote sensing: response to microphytobenthos and environment. Mar Ecol Prog Ser 367:57-72

- Webb WL, Newton M, Starr D (1974) Carbon-dioxide exchange of Alnus rubra: mathematical model. Oecologia 17:281-291

> Weerman EJ, van de Koppel J, Eppinga MB, Montserrat F, Liu QX, Herman PMJ (2010) Spatial self-organization on intertidal mudflats through biophysical stress divergence. Am Nat 176:E15-E32

> Weerman EJ, Herman PMJ, van de Koppel J (2011) Topdown control regulates self-organization on a patterned intertidal flat. Ecology 92:487-495

Zar JH (1999) Biostatistical analysis. 4th edn. Prentice Hall, Upper Saddle River, NJ

Appendix. Relationship between maximal fluorescence $F_{\mathrm{m}}$ and chlorophyll a concentration

The relationship between $F_{\mathrm{m}}$ values and chl a concentration $\left(\mathrm{mg} \mathrm{C} \mathrm{m}^{-2}\right)$ was estimated by analyzing chl a content and $F_{\mathrm{m}}$ values of different aged biofilms. These biofilms were grown as described in 'Materials and methods'. Chl a samples were taken from these biofilms by using the contact core method, where a metal disc was used to take a sediment sample, $2 \mathrm{~mm}$ deep, for chl a concentration analysis. A detailed description of this contact core method can be found in Honeywill et al. (2002). The sediment samples were freeze dried for $48 \mathrm{~h}$. These freeze-dried samples were analyzed in the laboratory to determine chl a concentration. Chl a content was determined spectrophotometrically after $48 \mathrm{~h}$ of $90 \%$ acetone extraction (Jeffrey \& Humphrey 1975). Data were analyzed using linear regression in R (www.R-project.org).

$F_{\mathrm{m}}$ values were positively correlated with chl a concentration in the top $2 \mathrm{~mm}$ of the sediment $(\mathrm{p}<0.001 ;$ Fig. A1). These results are in agreement with similar studies that correlated $F_{\mathrm{m}}$ values measured with a Pulse Amplitude Modulated Fluorometer (PAM) with chl a content (Honeywill et al. 2002, Kromkamp et al. 2006).

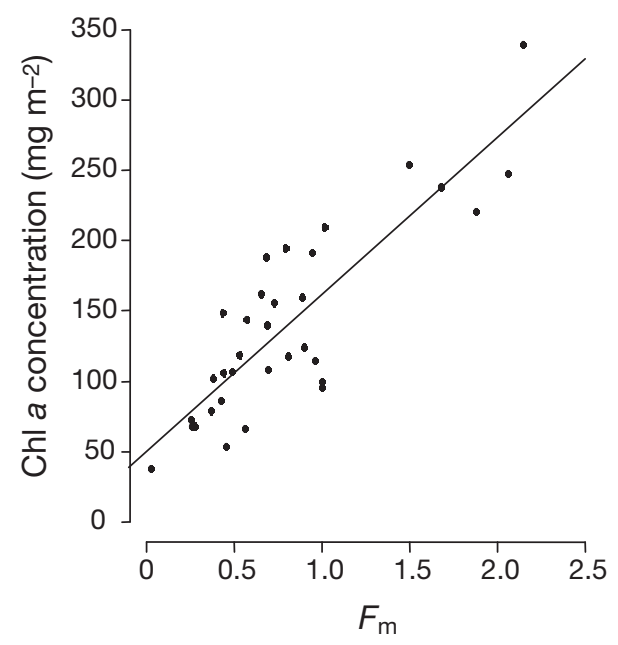

Fig. A1. Relationship between $F_{\mathrm{m}}$ (relative units) and chl a concentration $\left(\mathrm{mg}\right.$; linear regression, $\mathrm{p}<0.001, \mathrm{R}^{2}=0.73$ )

Editorial responsibility: Hans Heinrich Janssen, Oldendorf/Luhe, Germany
Submitted: February 15, 2011; Accepted: August 1, 2011 Proofs received from author(s): October 17, 2011 